\title{
Chapter 14 \\ The Impact of Land Cover Changes \\ on Socio-economic Conditions \\ in Bawlakhe District, Kayah State
}

\author{
Khin Sandar Aye and Khin Khin Htay
}

\subsection{Introduction}

In many regions of Myanmar, there is a close relationship between people and forests. A 2010 UN Food and Agricultural Organization (FAO) report found that $70 \%$ of Myanmar's total rural population, or approximately 30 million people, depend heavily on forests for their basic needs, and 500,000 people rely on forests for their employment (FAO 2010). However, according to the same study, between 1990 and 2010, a total of 7,445,000 ha, equivalent to $19.0 \%$ of Myanmar's total forest area, had been cleared. This gives Myanmar the seventh highest deforestation rate in the world (FAO 2010).

Forested land cover prevents soil depletion and erosion, sediment deposition in streams and rivers, and decline of biodiversity (Cunningham/Cunningham 2006). As such, changes in land cover have significance at global, regional and local levels (Lambin et al. 2001; Turner et al. 1990). Often a combination of economic, institutional, and political factors drive deforestation, including logging, agricultural expansion, infrastructure expansion, shifting cultivation and the extraction of non-timber forest products (NTFPs) and fuel wood (EIA 2015; Geist/Lambin 2001). In Myanmar, timber is an important export that occurs through both legal and illegal channels, especially hard woods such as teak. One recent study found that Myanmar exports 1.6 million tonnes of teak annually to neighboring countries such as India, China, Bangladesh, Thailand and Malaysia (EIA 2015).

Dr. Khin Sandar Aye, Professor, Geography Department, Loikaw University; Email: akhinsandar50@gmail.com.

Dr. Khin Khin Htay, Researcher, Geography Department, Loikaw University;

Email: Kkhinhtay.geog@gmail.com.

(C) The Author(s) 2019

C. Middleton and V. Lamb (eds.), Knowing the Salween River: Resource Politics

of a Contested Transboundary River, The Anthropocene: Politik-EconomicsSociety_Science 27, https://doi.org/10.1007/978-3-319-77440-4_14 
This chapter investigates land cover change, forest depletion, environmental degradation and ecosystem damage as it affects the livelihoods of local residents in Bawlakhe district, Kayah state. It uses both quantitative and qualitative tools in field data collection, and remote sensing (RS) and global information system (GIS) mapping tools to assess the social, economic and land cover changes in the study area (Bryman 2001). Bawlakhe district is located within the Thanlwin River Basin in Kayah state in Eastern Myanmar. The Thanlwin River flows north to south through Bawlakhe district, and the proposed Ywathit Dam is also located in the district in Ywathit sub-township (Middleton et al., Chap. 3, this volume). Bawlakhe district is composed of three townships (Bawlakhe, Hpasaung and Mese), 20 village tracts, and a total of 86 villages. ${ }^{1}$ This biodiverse area is home to a number of ethnic groups, including Kayah, Yintale and Shan, who depend on the watershed for food, water, security, fuel and income (Hla Tun Aung 2003). Within the study area, the majority of land is forested and the main source of income is shifting cultivation and employment in forest extraction and mining activities.

The research presented in this chapter finds that land cover conditions in this area have changed significantly since 1995, and especially after 2010. The dramatic decline of forest cover in this area has been caused by legal and illegal extraction of timber, in particular Teak (Tectona grandis) and Pyinkado (Xylia xylocarpa), together with over-cutting of fuel wood for domestic use and sale, expansion of shifting cultivation, and mining of lead. In this chapter, I identify three key time periods in which land cover, livelihoods, and governance changed significantly. The first period, prior to 2010, was characterized by armed conflict in Bawlakhe district. During this time, logging companies could not easily access the area due to risk of attack and land mines, and loss of forest cover was relatively limited. From 2010 to 2015, after a peace agreement was signed between local armed groups and the Union government, land cover changed dramatically as security improved and control of the territory was negotiated between the Myanmar military and armed groups. This allowed timber companies to log the area, rapidly depleting forest resources. Since 2016, the National League for Democracy (NLD) government has banned logging in the area.

While recent studies (EIA 2015; FAO 2010) have discussed some of the socio-economic factors that contribute to land use and land cover change, none have discussed Kayah state in detail, and to our knowledge this is the first research to report on the socio-economic impacts of land cover changes in Bawlakhe district. It is hoped that this research will provide local and regional decision-makers with accurate information to understand the implications of land use change, improve land use policy, and implement effective plans for regional sustainable development.

\footnotetext{
${ }^{1}$ Bawlakhe district is bounded to the east by Thailand, to the west by Kayin State, to the south by Thailand and Kayin State, and to the north by Loikaw district of Kayah state.
} 


\subsection{Methodology}

Qualitative and quantitative interviews were conducted in four villages in Bawlakhe district. The villages were selected on the basis of their relative distance from the Thanlwin River and their current forest cover density (Fig. 14.1: Location of four villages studied in Bawlakhe district). Bhukhu and Hose villages are both located far from the Thanlwin River. Bhukhu village is less densely forested than Hose Village. Wanpla and Wanaung villages are near the Thanlwin River. Forest cover in Wanaung village is less dense than in Wanpla village.

Field surveys were conducted from September 2015 to November 2016. Our research group was composed of seven people: two lead researchers and five research assistants. A questionnaire was administered in the four villages with 180 households (Table 14.1: Summary of the number of interviews per village). Respondents were selected on the basis of their experience in the area (5 years, 10 years, and 15 years) (Table 14.2: Summary of the number of interviews per village, by period of experience). Furthermore, only respondents over the age of 18 were

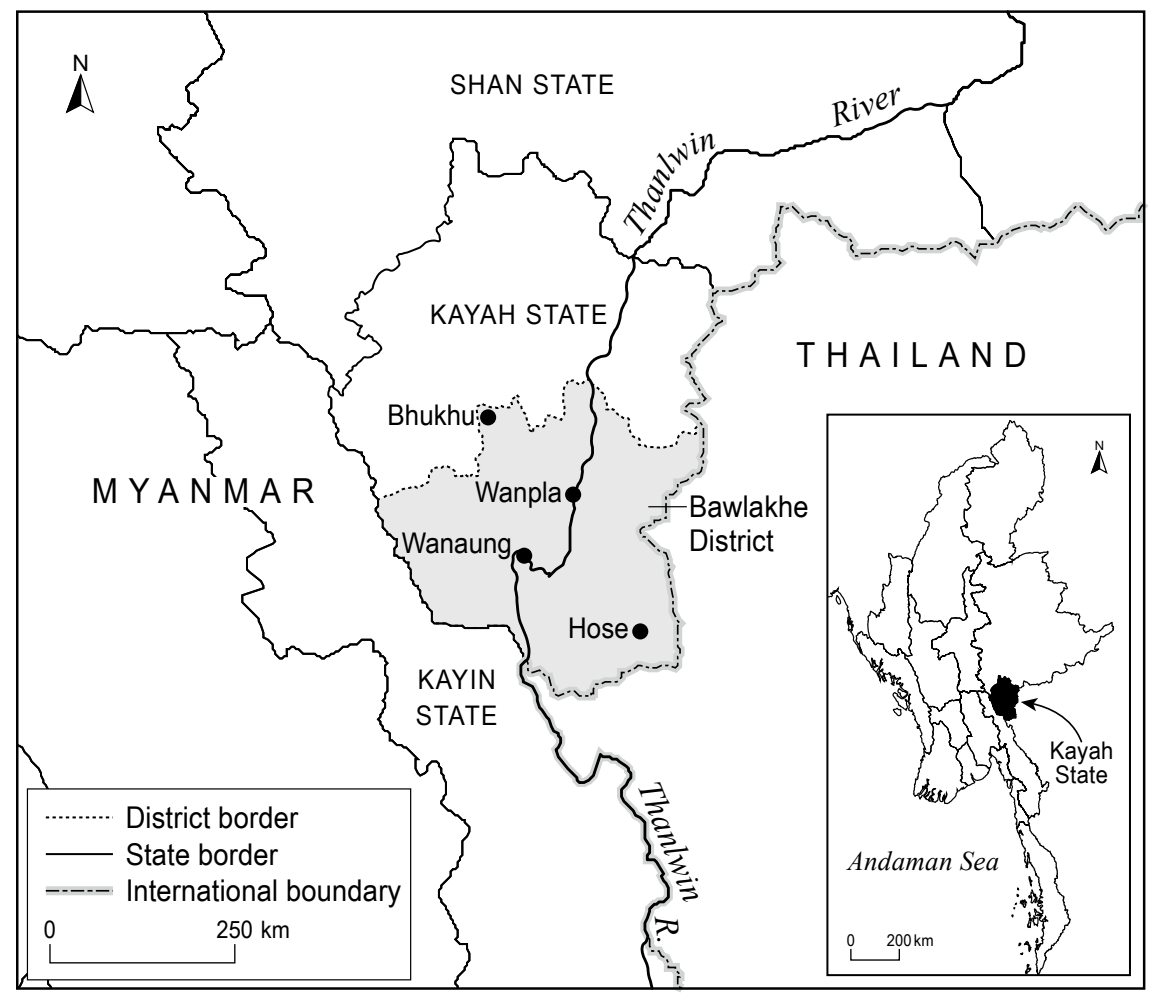

Fig. 14.1 Location of four villages studied in Bawlakhe district. Source Cartography by Chandra Jayasuriya, University of Melbourne, with permission 
Table 14.1 Summary of the number of interviews per village

\begin{tabular}{l|l|l|l|l|l|l}
\hline \multirow{2}{*}{ Village name } & \multicolumn{4}{l}{ Questionnaires } & \multicolumn{3}{l}{ Individual interviews (HH) } \\
\cline { 2 - 8 } & Male & Female & Total & Male & Female & Total \\
\hline Wanaung & 20 & 50 & 70 & 5 & 30 & 35 \\
\hline Wanpla & 5 & 15 & 20 & 4 & 11 & 15 \\
\hline Bhukhu & 3 & 12 & 15 & 2 & 8 & 10 \\
\hline Hose & 33 & 42 & 75 & 18 & 12 & 30 \\
\hline Total & 61 & 119 & 180 & 29 & 61 & 90 \\
\hline
\end{tabular}

Source The authors' field survey

Table 14.2 Summary of the number of interviews per village, by period of experience

\begin{tabular}{l|l|l|l|l|l|l|l|l}
\hline Village name & \multicolumn{2}{l}{$\begin{array}{l}5 \text { years } \\
\text { experience }\end{array}$} & \multicolumn{2}{l}{$\begin{array}{l}10 \text { years } \\
\text { experience }\end{array}$} & \multicolumn{2}{l}{$\begin{array}{l}15 \text { years } \\
\text { experience }\end{array}$} & \multicolumn{2}{l}{ Total } \\
\cline { 2 - 11 } & M & F & M & F & M & F & M & F \\
\hline Wanaung & 18 & 56 & 4 & 10 & 3 & 14 & 25 & 80 \\
\hline Wanpla & 3 & 18 & 3 & 7 & 3 & 1 & 9 & 26 \\
\hline Bhukhu & 3 & 10 & 1 & 8 & 1 & 2 & 5 & 20 \\
\hline Hose & 28 & 45 & 14 & 5 & 9 & 4 & 51 & 54 \\
\hline Total & 52 & 129 & 22 & 30 & 16 & 21 & 90 & 180 \\
\hline
\end{tabular}

Source The authors' field survey

interviewed, and gender balance was considered to ensure representation of both males and females. Sample selection by household ensured that $30 \%$ of all households in each village were represented (Table 14.3: Summary of village demographics and main livelihood activities). An additional 90 in-depth interviews were conducted with community members, government officials, and non-government organization staff (Table 14.1: Summary of the number of interviews per village). Finally, two or three focus group discussions were conducted per village. Each focus group discussion was composed of seven participants, and included village members who were aware of the history and patterns of settlement in the village. When the respondents could not speak Burmese, an assistant translated from Burmese to local ethnic languages.

Table 14.3 Summary of village demographics and main livelihood activities

\begin{tabular}{l|l|l|l|l}
\hline $\begin{array}{l}\text { Village } \\
\text { name }\end{array}$ & Population & Households & Ethnicity & Main livelihoods \\
\hline Wanaung & 493 & 93 & Shan/Yintale & $\begin{array}{l}\text { Logging, shifting cultivation } \\
\text { and livestock }\end{array}$ \\
\hline Wanpla & 268 & 87 & Shan & Logging, shifting cultivation \\
\hline Bhukhu & 266 & 49 & Kayah & Logging, shifting cultivation \\
\hline Hose & 1096 & 265 & $\begin{array}{l}\text { Kayah, Shan, Bamar, } \\
\text { Kayin }\end{array}$ & Logging, shifting cultivation \\
\hline
\end{tabular}

Source The authors' field survey 
The use of remote sensing and GIS technology can evaluate existing forest vegetation, land use and environmental conditions (Lillesand/Kiefer 2002). Many studies have been carried out using aerial photographs and Landsat TM remote sensing satellite (IRS-1A \& 1B) data (Chaung 2006; Campbell 1996; Kushwaha 1990; Pant/Kharkwal 1995; Roy et al. 1993). Land cover changes in Bawlakhe district were assessed using Landsat TM images from 1995, 2005, 2010 and 2015. The approach used in this study to classify satellite images and change detection was based on satellite images from Landsat 7 ETM \pm 1995, Landsat 7 ETM 2005 and 2010, and Landsat 8 ETM (2015) using a supervised classification method of the study area. Land cover classification was determined from satellite images using remote sensing software (Environmental Visualization Images (ENVI) version 5.0) and vector visualization using ArcGIS 10.2 software. Forest classification was defined according to Hla Tun Aung (2003). The classifications were triangulated with qualitative data gathered from interviews in the four villages and the researchers' observations. In this analysis, the use of images was the same, and the images were taken within two months of each other, which led to slight seasonal variation. Taking this into account, sub-tropical wet hill forest areas occur more frequently than other forest types in Bawlakhe district for 2015.

\subsection{Land Cover Change and Livelihoods in Bawlakhe District}

There are seven types of land cover in Bawlakhe district: (1) Tropical wet evergreen forest; (2) Sub-tropical wet hill forest; (3) Sub-tropical hill savanna forest; (4) Paddy land; (5) Water bodies; (6) Fallow land; and (7) Settlements (Hla Tun Aung 2003). According to Myanmar's legal classification of forest types, in Bawlakhe district $65 \%$ of the total area is considered forestland, and of this $7 \%$ is "reserved forest" and over $70 \%$ is "unreserved forest."

The majority of land cover in Bawlakhe district is forest land. The 3,000 feet contour is an important determinant of forest type in Myanmar. Hill forests are found above 3,000 feet, while evergreen and mixed forests occur below that altitude. However, due to human activities including logging, shifting cultivation, and extraction of NTFPs and fuel wood, the type of forest cover has changed in Bawlakhe district. ${ }^{2}$ In general, forestland has become degraded and significant parts of the area have less vegetation cover than previously.

\footnotetext{
${ }^{2}$ Kayah State is also rich in minerals, especially tin, wolfram (tungsten) and antimony. The most important mine is the Mawchi mine, which produces tin and wolfram. This area lies in the Bawlakhe area and it is one of the causes of forest decline. British companies were the main extractors of minerals in the early days in the Mawchi area. In 1962, the government nationalized mining and took over the operation of the country's main mines on a joint-venture basis. The mining industry exists now as a joint venture. 150 tons of lead is extracted annually in the Bawlakhe area.
} 
Before detailing the forest transitions that have occurred in Bawlakhe district, I briefly detail the types of forest. Tropical wet evergreen forest occupies the central part of Kayah State. Big, tall, isolated evergreen trees form the main canopy, which may be less continuous than in other areas. Single giant dipterocarps or other trees may stand above the level of the canopy. Middle and lower levels are characterized by dense green vegetation. Bamboos, dense masses of climbers, and canes occur abundantly. In 1995, this type of forest was found in the lower sub-tropical hill savanna forest areas. In 2015, these areas especially occupy the central part of the area.

Sub-tropical hill savanna forest is found in the western, northern, and eastern parts of Bawlakhe district, and in the north-central hills. These forest types are rich in biodiversity and valuable timber. Forest products found in this type of forest include teak and other hardwoods such as Pyinkado, Padauk and Ingyin, along with bat manure, lac, cutch, resin and honey. Pines are also scattered in sub-tropical hill savannah forest areas. In 1995, sub-tropical hill savanna forest covered about one third of Bawlakhe district, and this forest type area was found in the eastern and southeastern parts of the district in 2015. Big, tall, isolated evergreen green trees form the main canopy which may be less continuous than other areas. Single giant Dipterocarps or other trees may stand up above the level of the canopy. Middle and lower levels are green and dense. Bamboos, dense masses of climbers, and canes occur abundantly.

Sub-tropical wet hill forest is found in the central foothill areas. Several species of bamboo are found in sub-tropical wet hill forest areas, and woody climbers, root climbers and epiphytes are abundant. Forest products found in these areas include teak and other hardwoods such as Pyinkado, Padauk and Ingyin, as well as lac, cutch, resin and honey.

Within the study area, political conditions have had a direct impact on land cover change. The following sections detail land cover change during the period of armed conflict before 2010 and the five-year period following peace agreements $(2010$ 2015), followed by a brief discussion of the most recent period after the establishment of the new government in Myanmar (2016-present). Each section details land cover conditions, then provides an analysis of the local political situation leading to the socio-economic conditions that have contributed to land use change.

\subsubsection{Period of Armed Conflict (Before 2010)}

From 1995 to 2005, sub-tropical hill savanna forest, tropical wet evergreen forest and sub-tropical wet hill forest were found in the western, northern and eastern parts of Bawlakhe district. Respondents who lived in these areas for a period of between 10 and 15 years described the previous land cover type as "forestland." According to data on land cover change and field surveys, there are both similarities and differences between the villages. Over the decade between 1995 and 2005, sub-tropical hill savanna forest and sub-tropical wet hill forest cover declined, with tropical 


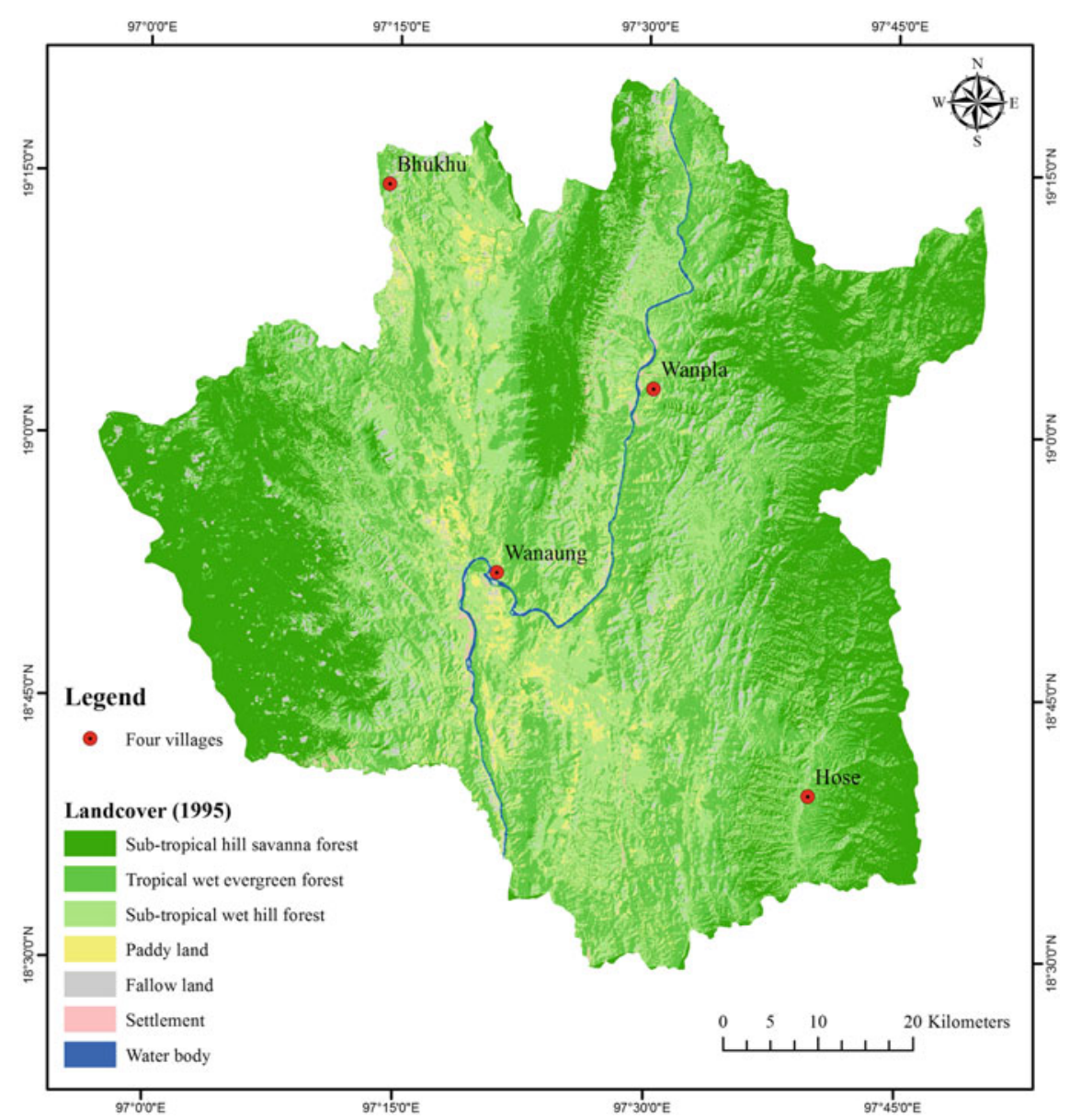

Fig. 14.2 Land cover conditions in Bawlakhe district, 1995. Source Landsat 7 ETM \pm 1995

evergreen forest becoming more prevalent (Fig. 14.2: Land cover conditions in Bawlakhe district, 1995; Fig. 14.3: Land cover conditions in Bawlakhe district, 2005; Table 14.4: Land cover conditions in Bawlakhe district in 1995 and 2005).

Prior to 2010, Bawlakhe district had a wealth of forest products, and commercial forest production was moderate. Local people could provide for their livelihoods through the collection of fuel wood, pole wood, and NTFPs such as honey, orchids, and medicinal plants. Subsistence agriculture was also important, with most of the farming done by shifting cultivation. After clearing a forest area, the local people would use a plot of land for three to four years before clearing a new forest area and leaving the old field fallow (Bryant 1994). The main source of fuel for cooking was firewood, namely Pyinkado (Xylia xylocarpa). When a tree was felled, villagers 


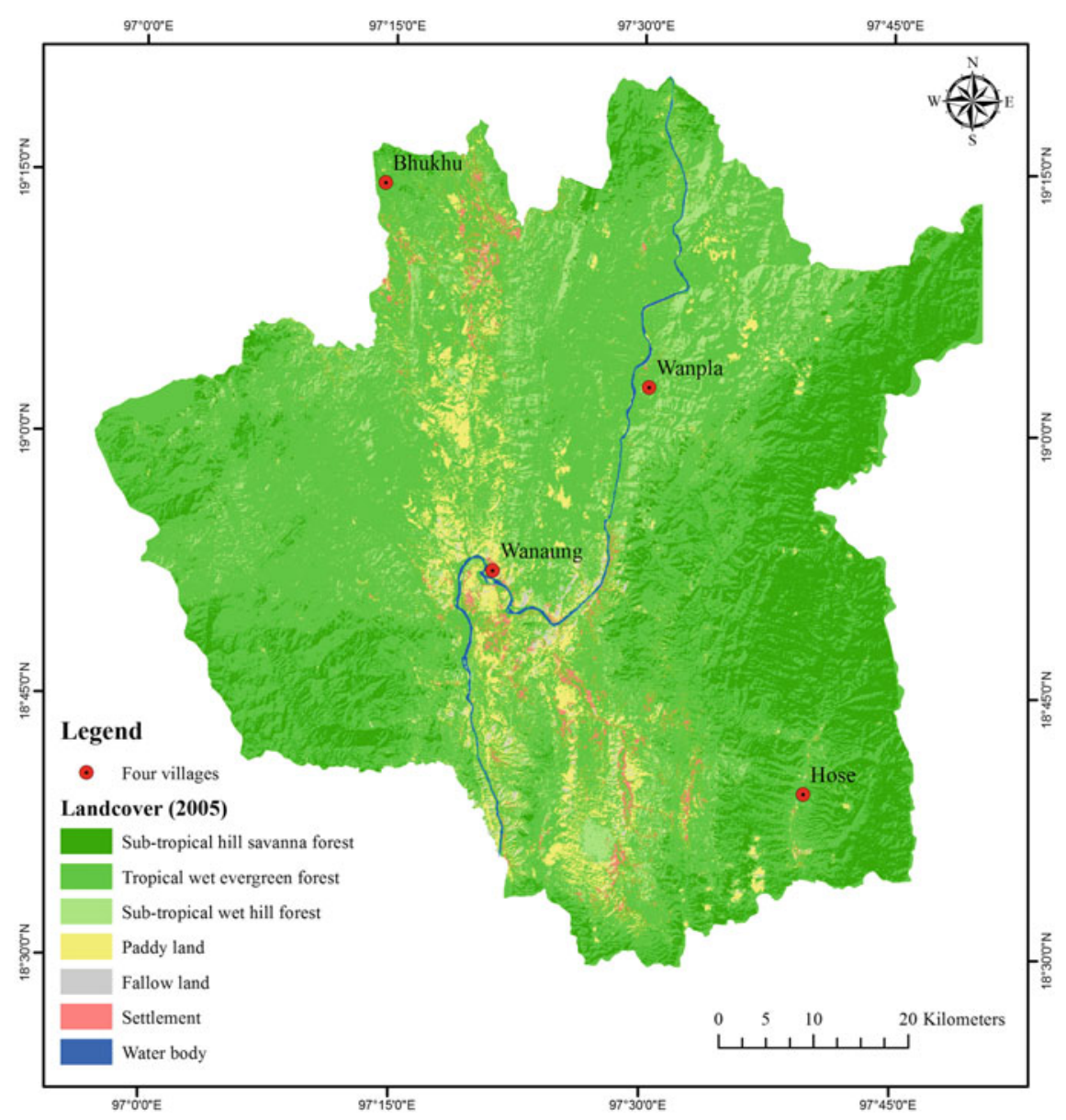

Fig. 14.3 Land cover conditions in Bawlakhe district. Source Landsat 7 ETM \pm 2005

Table 14.4 Land cover conditions in Bawlakhe district in 1995 and 2005

\begin{tabular}{l|c|c}
\hline Land cover types & $1995\left(\mathrm{~km}^{2}\right)$ & $2005\left(\mathrm{~km}^{2}\right)$ \\
\hline Sub-tropical hill savanna forest & 3066.9 & 639.3 \\
\hline Tropical wet evergreen forest & 740.0 & 3847.8 \\
\hline Sub-tropical wet hill forest & 940.8 & 251.2 \\
\hline Paddy land & 212.8 & 199.7 \\
\hline Fallow land & 162.4 & 149.7 \\
\hline Water bodies & 22.3 & 20.8 \\
\hline Settlements & 20.9 & 57.4 \\
\hline
\end{tabular}

Source Based on Figs. 14.2 and 14.3 
would remove the branches and cut the trunk, which could be up to two feet in diameter, into pieces to carry back to the village for firewood (Individual interviews, 2015 and 2016).

Prior to 2010, armed conflict was frequent in Kayah state. Armed groups would extract timber and trade it across the border to Thailand. However, conflict in Kayah state and the threat of attacks and landmines made it dangerous for larger timber companies to access the area. Kayah and Shan ethnic armed groups were dominant in Wanaung, Wanpla and Hose villages. During this period of conflict, many villagers relocated to safer areas within the region. Therefore, while armed groups and local people were able to access and extract forest products from the area, very few outside companies engaged in commercial wood extraction during this time. Starting in May 1997, five armed groups in Kayah state ${ }^{3}$ began negotiating a cease-fire agreement with the Myanmar Union Government, which was signed in 2010 (Hla Tun Aung 2003).

\subsubsection{Following the Peace Agreement (2010-2015)}

The past ten years has seen an increase in deforestation and a decrease in the quality of timber in Bawlakhe district. This has changed the lives of villagers in each community. This section details the changes that have occurred in each village, and the socio-economic implications of those changes. After 2010, when the peace agreement between the military and armed groups was signed, security improved that allowed both private and state logging companies access to forests. Forest cover in Bawlakhe district dramatically changed as logging became more intensive. As more armed groups entered into ceasefire agreements, the area where there was no longer violent conflict extended. Reserved forest, nursery gardens and sawmills were established in government-held areas. There are now two sawmills: one in Bawlakhe township and one in Hpasaung township.

Between 2010 and 2015, the most significant land cover changes occurred in the study area, with an overall decline in forest cover (Fig. 14.4: Land cover conditions in Bawlakhe district, 2010; Fig. 14.5: Land cover conditions in Bawlakhe district, 2015; Table 14.5: Land cover conditions in Bawlakhe district in 2010 and 2015). By 2015, sub-tropical wet hill forest was more prevalent than other forest types in Bawlakhe district. According to our questionnaires, people who had lived in the study area less than five years had not witnessed much land cover change; however, people who had lived in the area longer than five years explained that the overall diversity and quantity of flora and fauna has decreased. Additionally, villagers who had lived in the study area longer than five years noted changes to the watershed, with some streams now dry, even during the rainy season. Some forestland has also

\footnotetext{
${ }^{3}$ Kayan National Defense Guards (KNG), Kayinni National Liberation Front (KNLF), Kayan Pyithit Party (KPP), and Kayinni National Progressive Party (KNPP).
} 


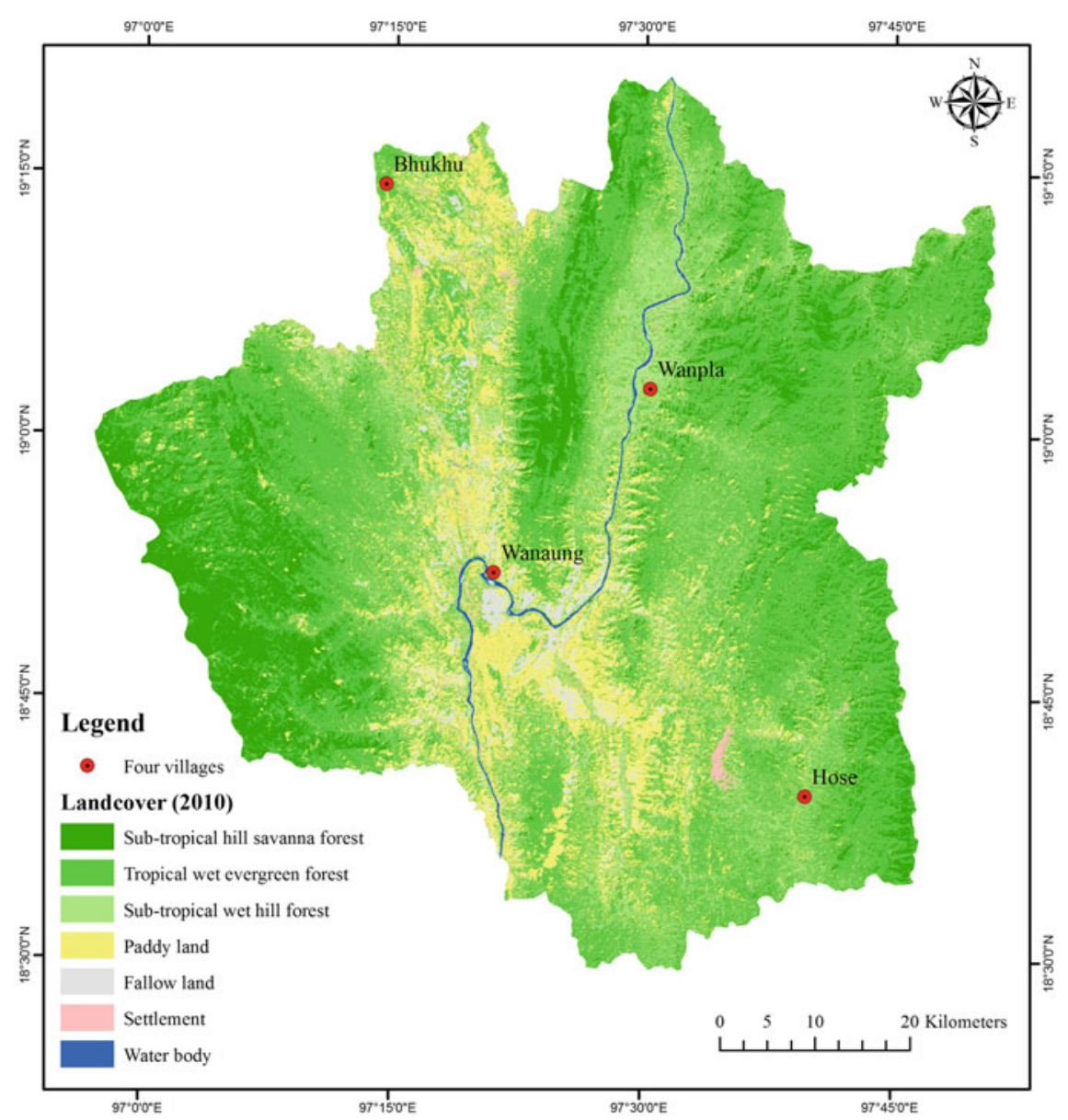

Fig. 14.4 Land cover conditions in Bawlakhe district, 2010. Source Landsat 7 ETM (2010)

changed to settlement land or cultivated land. The changes occurred gradually, with the forestland decreasing daily. Remotely sensed data shows that significant changes have taken place in the Bawlakhe district, with more degraded forest and settlement areas now apparent (Table 14.5: Land cover conditions in Bawlakhe district in 2010 and 2015).

There are both similarities and differences between the villages, including particular livelihoods and migration patterns. Before 2010, people who lived in this area depended on a modest amount of forest production and collecting NTFPs for their livelihoods. After 2010, when private and state logging companies began accessing the forests, many people from other places, especially central Myanmar, came to work in the area. Between 2010 and 2015, both local people and migrants worked in forest production for their main livelihood. A 2012 study shows that 


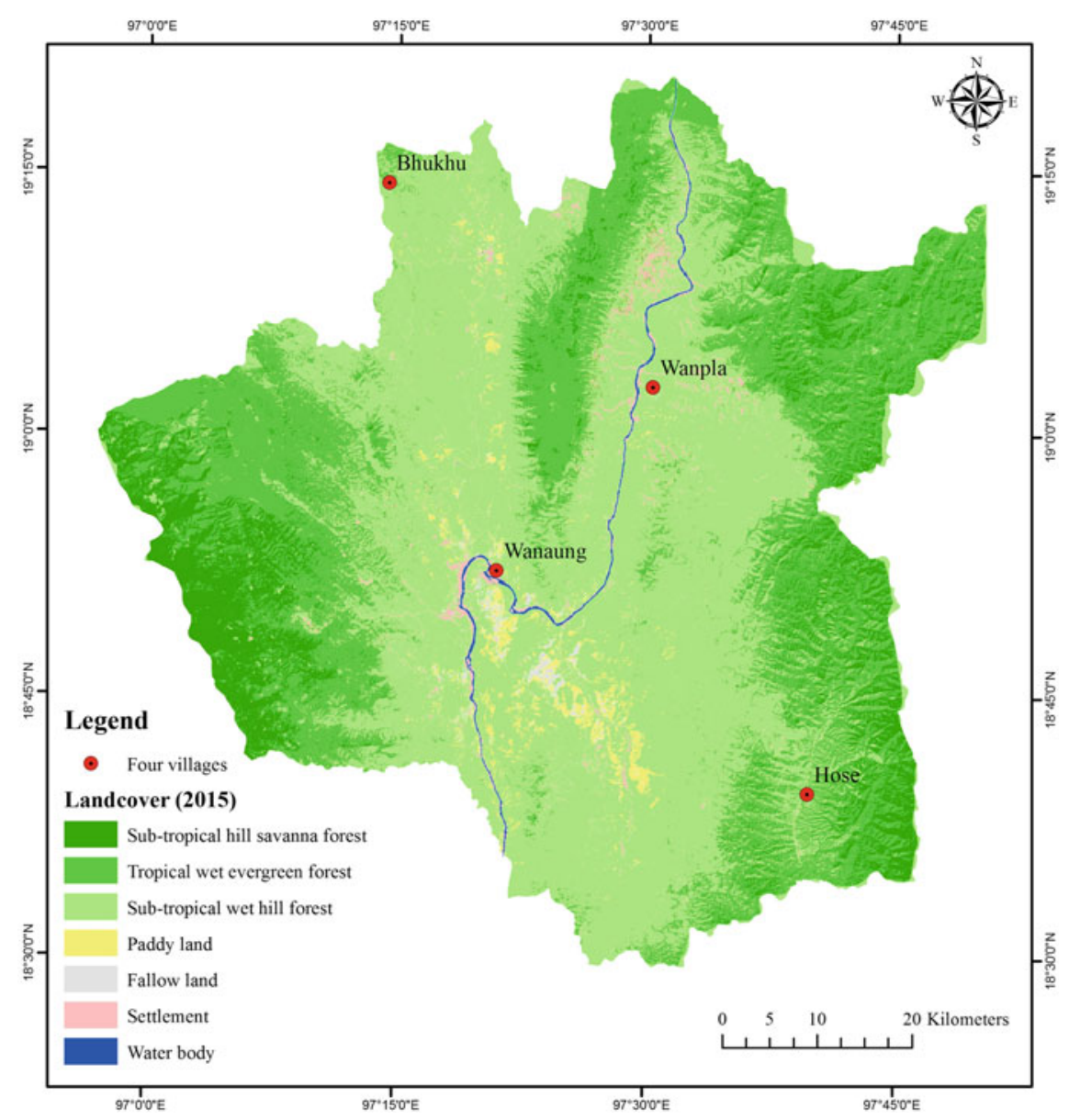

Fig. 14.5 Land cover conditions in Bawlakhe district, 2015. Source Landsat 8 ETM (2015)

Table 14.5 Land cover conditions in Bawlakhe district in 2010 and 2015

\begin{tabular}{l|c|c}
\hline Land cover types & $2010\left(\mathrm{~km}^{2}\right)$ & $2015\left(\mathrm{~km}^{2}\right)$ \\
\hline Sub-tropical hill savanna forest & 501.9 & 444.5 \\
\hline Tropical wet evergreen forest & 2312.6 & 1596.3 \\
\hline Sub-tropical wet hill forest & 1706.0 & 2795.9 \\
\hline Paddy land & 459.0 & 100.0 \\
\hline Fallow land & 94.0 & 89.4 \\
\hline Water bodies & 79.8 & 18.4 \\
\hline Settlements & 13.2 & 121.5 \\
\hline
\end{tabular}

Source Based on Figs. 14.4 and 14.5 
during this time, 20,000 tons of rattan cane, 16,030 visses of bat manure, ${ }^{4} 1,596$ tons of charcoal, 310 tons of firewood, 345 visses of bamboo and 70 visses of honey were produced annually in Bawlakhe district (Politno 2012). According to our interviews, during this period all of the men worked in forest extraction, while women worked in housekeeping and cultivated vegetables, shifting agriculture, and paddy rice for household consumption.

The peace agreements had significant impacts on all aspects of peoples' livelihoods. Outsiders also migrated into the area in search of job opportunities, fueled by the border trade with Thailand, which increased the population. As markets in Thailand and other parts of Myanmar became accessible, reflecting evolving policies of the neighboring countries as well as improved infrastructure, occupations shifted to forest production, crop cultivation, the sale of charcoal, and animal husbandry (cows and goats) for export to Thailand. Most villagers interviewed had around two acres of cultivated land, and more families began to cultivate land as did new arrivals to the area. Residents in three of the four villages - Wanaung, Wanpla, and Bhukhu - also began growing sesame for sale to Hpasaung township and Thailand. In addition to increased forest extraction and changes in the agricultural sector, infrastructure development and road networks also contributed to land use and land cover change.

In 2012, the Union Solidarity and Development Party (USDP) government began to implement a "Greening Project" across the country. The Ministry of Agriculture, Livestock, and Irrigation and the Department of Livestock, Fisheries and Rural Development worked with the local government to implement the Greening Project. Through this project, the government provided loans to local people for agriculture and animal husbandry, and for building new houses. The aim of the project was to raise the standard of living in rural upland regions to a level more equitable with urban areas. The government cooperated with local organizations to raise funds for poverty alleviation. Through this project, the state and local government built housing, schools and hospitals to fulfill the needs of community members. The government's rural development plan also included "Rural Road Development," which entailed the construction of roads 30 feet in width directly connecting each and every village with nearby highways or motorways (Politno 2012). This government policy played a major role in the development of the town and villages in Bawlakhe district.

Changing political conditions after the 2010 peace agreements, along with the Greening Project, increased socio-economic opportunities for villagers in forest production and growing cash crops. However, these political conditions did not result in universal land use changes. For example, after 2010, villagers from Bhukhu village moved from the uplands to either the eastern lowland foothills or further away to Hpasaung township to facilitate easier access to markets. In the foothills, transportation and communication improved because there was no longer active conflict, and later the Greening Project brought some infrastructure

\footnotetext{
${ }^{4}$ One viss is approximately 1.63 kilograms (3.6 pounds).
} 
development. However, some people were not able to support their livelihoods because their skills were mainly related to gathering forest products and shifting cultivation, which they could not practice in the lowland areas. According to one respondent from Bhukhu village, "some people returned to the old area because there was forest land and shifting cultivation land still available" (Bhukhu village interview, 23 October 2015).

In general, according to our interviews, additional work in timber extraction and forest production increased people's incomes in the four villages. Local people could now afford modern amenities like televisions, solar panels for electricity, water pumps, tractors, and motorbikes. Some people still remained jobless, however. Some young people, especially young adult men, went to Thailand to work.

Not all people welcomed the socio-economic changes brought about by the peace agreements and broader transformations in Myanmar, however. According to interviews, for some people the logging area was too far away and the work too difficult, that they did not want to move to another village. As one respondent stated, "We don't have modern facilities, but we don't want to move to another area" (Wanpla village interview, 2 December 2015). The enticement of money and modern amenities was not a sufficient reason for everyone to want to move. As one respondent explained "We are not educated and rich, but we are happy" (Wanaung village interview, 3 March 2015).

Overall, during the 2010-2015 period, the political changes that brought peace to the area also expanded border trade and increased opportunities for cultivating cash crops, and, most significantly, increased forest extraction by large private companies. Forest cover dramatically decreased and many forest products are now much harder to access or are gone. By 2015, forest cover had been degraded and depleted, and most of the logging companies moved away. Therefore, by the end of this period, some local people began moving to other areas of Myanmar and to neighboring countries to seek work.

\subsubsection{The NLD Government Period (2016-Present)}

After the 2015 election, the new NLD government came into power on April 1st, 2016 and implemented a one-year logging ban throughout the country (Trautwein 2016). According to 2016 records, the Forest Department established two state-owned forests and seven community forests in Bawlakhe district. Meanwhile, near the end of 2015, and as a part of the Greening Project, Hose village and local armed groups accepted the government policy to start replanting teak and hardwood.

As a result of the Greening Project, some people received new houses, while others moved to Hpasaung township in Bawlakhe district. In Wanaung village, the Greening Project has extended the settlement area to the western bank of the Thanlwin River. At the same time, Shan residents live on the eastern bank of the Thanlwin River, and an armed group is also based there. Before 2015, the economy 
of the study area was based on timber extraction, agriculture, animal husbandry, and mining. Timber extraction has moved outside of Bawlakhe district, limiting forest production in the area. However, charcoal production still provides local people with income. At present, limitations on forest production are leading to livelihood problems for local residents. According to questionnaires and individual interviews, over $80 \%$ of respondents described the forest area as far from the village and indicated that the collection of forest products has decreased. As the main economy of the area has long depended on the forest and forest products, many villagers are now jobless and some have moved to other parts of Myanmar and overseas to seek job opportunities. Some of the families who have lived in this district for more than five years have moved to other parts of Kayah and Shan states for their livelihoods because the local economy is dependent on forest production.

However, since 2015, some villagers in the district have started to raise more livestock and have changed their crops and farming methods. The agricultural land use changes that began in the 2010-2015 period have continued, with people extending their agricultural land to grow cash crops such as sesame and to raise livestock (goats and cows) for export to Thailand illegally. Hose village is located near the Thai-Myanmar border, and villagers began to grow sesame and garlic in 2014, and cardamom (Elettaria cardamomum) as a commercial cash crop in 2016. In 2017, the other three villages also began growing cardamom for sale mostly to Chinese markets.

\subsection{Implications of Land Cover and Livelihoods Changes}

Both our quantitative RS and GIS data, and observations gathered by interviews and group discussions, reveal that forestland has declined in the area (Table 14.6: Changes in land cover in Bawlakhe district from 1995 to 2015). Forest products can no longer be collected near the villages because of the heavy logging that occurred, along with the expansion of settlement areas, grazing land, and agriculture. When timber companies arrived in 2010, many local people sought employment in logging, but the lack of a forest conservation and management plan led to significant forest depletion, which inevitably impacted the villagers' livelihoods and their broader relationship with the forest. Because the main source of income in this area

Table 14.6 Changes in land cover in Bawlakhe district from 1995 to 2015

\begin{tabular}{l|l|l|l|l}
\hline Land cover types & $1995\left(\mathrm{~km}^{2}\right)$ & $2015\left(\mathrm{~km}^{2}\right)$ & Decrease $\left(\mathrm{km}^{2}\right)$ & Increased $\left(\mathrm{km}^{2}\right)$ \\
\hline Sub-tropical hill savanna forest & 3066.9 & 444.5 & 2622.4 & - \\
\hline Tropical wet evergreen forest & 740 & 1596.3 & - & 856.3 \\
\hline Sub-tropical wet hill forest & 940.8 & 2795.9 & - & 1855.1 \\
\hline Paddy land & 212.8 & 100 & 112.8 & - \\
\hline Fallow land & 162.4 & 89.4 & 73.0 & - \\
\hline Water bodies & 22.3 & 18.4 & 3.9 & - \\
\hline Settlements & 20.9 & 121.5 & - & 100.6 \\
\hline
\end{tabular}

Source Data from Tables 14.4 and 14.5 
depends on forest production, decreased forest cover has forced people to change their livelihoods. Some people have moved to other regions of Myanmar, while some people have migrated to neighboring countries.

Political changes in the country have been the greatest contributing factor to land cover change. The status of ceasefire agreements and location of conflicts have influenced when and where government agencies and non-state businesses are able to access forest resources for logging. Prior to 2010, most of the shifts in type of forest cover and land use changes occurred at a smaller scale because of conflicts. After 2010, however, most of the land use changes occurred from logging and resulted in the depletion of forest cover. Currently, depletion of forestland has reduced the availability of resources available for logging, and national policy discourages timber extraction. However, it is too soon to tell whether this will lead to a recovery of forest cover. These political changes, along with the sudden increase then decrease in forest production, has significantly impacted the livelihoods of local people, as they rely on forest products both for their own use and for economic opportunities through jobs in the forest sector.

In Myanmar, where populations are widely dispersed and infrastructural challenges limit the free flow of information, there is a great need to enhance awareness amongst national policy makers about local needs and aspirations. This was a key motivation for undertaking our field research. Before 2010, Kayah state lacked a clear plan for forest conservation and management. Thus, today, forest depletion is a key challenge, with strong impacts on community livelihoods. The remainder of this chapter will focus on the implications of our research for forest protection, land governance, and policy.

\subsection{Implications for Forest Protection and Local Livelihoods}

The economy of Bawlakhe district depends on forest production, and agriculture is mainly subsistence-based. Our RS data and surveys show that significant changes have taken place in the Bawlakhe district, in particular forest degradation and expanding settlements. The most remarkable changes in land use classes occurred from 2005 to 2015. Spatially, most land use change occurred in the central part of the study area due to easy access to commercial areas and increased settlement following road improvement and other infrastructure development. The decrease in forest cover has impacted water sources, and increased agricultural land cover and settlements have also contributed to ecosystem changes. Limited availability of wild animals and plants impacts local people who are dependent upon animals and plants for their livelihood. The lack of a plan for natural resource conservation and utilization has led to unsustainable land use changes, which gives rise to socio-economic and environment problems that are inadequately addressed by policy responses. 


\subsection{Changing Land Cover Governance}

Deforestation is driven by regional economic, institutional, and policy factors which have led to agricultural expansion, logging, and infrastructure development (Angelson/Kaimowitz 1999; Lambin et al. 2001). Our research found that agricultural expansion and shifting cultivation contributed to forest depletion in all four villages. Local people rely on the forest for building materials, medicinal plants, food, orchids, fuel wood, and hunting. They also collect these products from forest areas and sell them for their livelihoods.

Timber extraction, particularly the production and export of teak wood, is the major economic activity in Kayah state, and the main cause of forest degradation is legal and illegal timber extraction by large private companies and the government. However, local people in this area also depend heavily on timber extraction for their incomes.

In January 2016, the USDP government passed a new National Land Use Policy that aims to systematically manage land use and tenure rights in the country, including both urban and rural areas. The objectives of the policy include harmonization and implementation of existing laws related to land. The policy also provides guidance to relevant departments and organizations on issues related to land use and tenure rights. While this policy has significant implications for the study area, at the time of the field research it had not yet been implemented and therefore its on-the-ground impact cannot be assessed. Furthermore, there is now a growing recognition amongst the government that a National Land Law is required to implement the National Land Use Policy (Pyae Thet Po 2018). This is particularly the case given a recent amendment to the Vacant, Fallow and Virgin Land Management Law in 2018 that civil society has flagged could exclude communities from customary land tenure rights (Gelbort 2018). There is also a recognition that historical and ongoing land grabbing in Myanmar is an urgent issue that must be resolved (Scurrah et al. 2015).

\subsubsection{Future Policy Implications}

Forest cover decline, land use changes, and the socio-economic conditions of local people in Bawlahke district are linked to political changes in the region and the country. Changes in forest cover have had a direct impact on people's livelihoods, and there is a great need to enhance policy makers' awareness of local needs.

The majority of deforestation and forest degradation has occurred from legal and illegal timber extraction by large private companies and the government, which employ both migrants and local people. A key conclusion of this chapter is that there is a large gap in knowledge about environmental conservation on the part of companies, local governments, and communities. Land use decisions need to fully 
consider the implications of deforestation on eco-system health, local livelihoods, and the sustainability of future timber extraction activities.

In addition to providing income through timber extraction, local people rely heavily on the forest for food, water, medicine, and fuel wood. Government conservation efforts should include the establishment of more community forests in the area. This would promote sustainable forestry management within local communities and allow continued access to the NTFPs that local people rely on for their livelihoods.

There is also limited access to formal education available to people in the study area. Nearly $95 \%$ of the people interviewed had no formal education, and the remainder had only primary school education. Government conservation policies should therefore include capacity building in communities, including access to formal education.

New approaches to regional development should also be considered. For example, in 2017, Mae Hong Song Province in Thailand signed a Memorandum of Understanding with Kayah state to increase tourism along the border area. Mae Hong Song and Loikaw have now been declared sister cities. The beautiful mountain scenery has high tourist potential, with good income prospects for local communities. Sparse forest settlement patterns along the Thai-Myanmar border create potential for eco-tourism, which could lead to new job opportunities.

Lastly, as the NLD party continues to implement the Land Use Policy (2016) passed by the previous government, the use of remote sensing techniques in combination with ground surveys is recommended for better planning and sustainable management of land cover area in Bawlakhe district. Remote sensing allows for monitoring of land cover changes, while ground surveys help explain the causes of land use cover change and understand the local context more thoroughly. Improved data collection methods could lead to greater clarity around socio-economic and environmental changes in the area. For future development, it is important to systematically evaluate previous patterns and dynamics of land use. Land use change based on time series analysis will provide insight into sustainable resource utilization and conservation.

\subsection{Conclusion}

Humankind must use the environment sustainably in order to survive. Without conservation practices, long-term environmental degradation sets in, threatening human survival (Wilson/Bryant 1997). For sustainable land use, access to reliable data and means to interpret and act upon it are vital (Anderson et al. 1996). Projections for future land-cover patterns are also needed to evaluate the implications of human action on the future of ecosystems (Turner et al. 1995).

This chapter is one of the first studies to assess in detail how land cover changes relate to the socio-economic conditions of the population in Bawlakhe district. The causes of forest degradation are many and varied. In using digitally processed 
Landsat Imagery to compare each location over time, we could assess land cover changes in Bawlakhe district. What we found was that between 1995 and 2015, there was a significant decrease in forest cover. The field surveys and interviews added to our understanding of these changes by illustrating some of the socio-economic conditions that contributed to this land cover change.

A key finding of this study is that forest depletion and changes in land utilization have caused changes in the local economy. Sub-tropical hill savanna forest in particular, which is rich in species and valuable timber, has decreased in the area. As forest extraction increased to meet the demands for cash income, depleted forest resources have limited the availability of forest products. In the study area, legal and illegal extraction of timber, over cutting of fuel wood, and extension of agriculture land has already decreased forest cover area. Timber extraction has now shifted to other forested areas, and fuel wood must now be collected far from the village. Some people have moved to other areas, including neighboring countries, some have begun to cultivate different crops, and some are raising animals for export. Within the four villages studies, over $40 \%$ of the residents have changed their livelihoods from forest production to other economic activities.

A final key finding of this study is that forest depletion and changes in land use take place when political circumstances change and villagers seek to change their socio-economic status. There is a lack of planning for natural resource conservation and utilization on the part of all actors. The government must increase efforts to raise awareness of environmental conservation and land use development policy in the area, while supporting the development needs of the local people. For example, the government should promote community-based natural resource management in villages. Policies and guidelines for sustainable development that guide local and regional decision makers should be informed with accurate information to understand the impacts of land use change. Ultimately, policies that discourage deforestation and forest degradation and support local livelihoods are needed in Bawlahke district.

\section{References}

Anderson, L.E. (1996). The causes of deforestation in Brazilian Amazon. Journal of Environment and Development, 5, 309-328.

Angelsen, A., \& Kaimowitz, D. (1999). Rethinking the causes of deforestation: Lessons from economic models. The World Bank Research Observer, 14, 73-98.

Bryant, R.L. (1994). Shifting the cultivator: The politics of teak regeneration in colonial Burma. Modern Asian Studies, 28(2), 225-250.

Bryman, A. (2001). Social research methods. Oxford, United Kingdom: Oxford University Press. Campbell, J.B. (1996). Introduction to remote sensing. New York, NY: Guilford Publications.

Center for Diversity and National Harmony. (2015). The State of harmony in Kayah State. Yangon, Myanmar. Retrieved from: http://www.cdnh.org/publication/data/the-state-of-socialharmony-in-kayah-state-quantitative-data/.

Chaung, K.T. (2006). Introduction to geographic information systems. New York, NY: McGraw-Hill. 
Cunningham, W., \& Cunningham, M. (2006). Principles of environmental science: Inquiry and application (3rd ed.). New York, NY: McGraw-Hill Companies.

EIA (Environmental Investigation Agency). (2015). Organized chaos: The illicit overland timber trade between Myanmar and China. London, United Kingdom. Retrieved from: https://eiainternational.org/report/organised-chaos-the-illicit-overland-timber-trade-between-myanmarand-china/.

FAO (Food and Agriculture Organization). (2010). Global forest resources assessment 2010: Main report. FAO forestry paper (Vol. 163). Rome, Italy: FAO. Retrieved from: http://www. fao.org/docrep/013/i1757e/i1757e.pdf.

Geist, H.J., \& Lambin, E.F. (2001). What drives tropical deforestation? A meta-analysis of proximate and underlying causes of deforestation based on subnational scale case study evidence. LUCC Report Series No. 4. Louvainla-Neuve, Belgium: University of Louvain.

Gelbort, J. (2018, December 10). Implementation of Burma's Vacant, Fallow and Virgin Land Management Law: At Odds with the Nationwide Ceasefire Agreement and Peace Negotiations. Transnational Institute. Retrieved from: https://www.tni.org/en/article/implementation-ofburmas-vacant-fallow-and-virgin-land-management-law.

Hla Tun Aung. (2003). Myanmar: The process and patterns. Yangon, Myanmar: National Center for Human Resources Development, Ministry of Education.

Kushwaha, S.P.S. (1990). Forest type mapping and change detection from satellite imagery. ISPRS Journal of Photogrammetry and Remote Sensing, 45, 175-181.

Lambin, E.F., Turner, B.L., Geist, H.J., Agbola, S.B., Angelsen, A., Bruce, J.W., \& Xu, J. (2001). The causes of land-use and land-cover change: Moving beyond the myths. Global Environmental Change, 11(4), 261-269.

Lillesand, T.M., \& Kiefer, R.W. (2002). Remote sensing and image interpretation. New York, NY: Willy.

Pant, D.N., \& Kharkwal, S.C. (1995). Monitoring land use change and its impact on environment of central Himalaya using remote sensing and GIS techniques. Journal of Hill Research, 8(1), $1-8$.

Politno. (2012). Geographical study on the settlement patterns of Bawlakhe District (Unpublished Master's thesis). Loikaw University, Loikaw, Myanmar.

Pyae Thet Phyo. (2018, October 8). Vice president says country needs National Land Law. Myanmar Times. Retrieved from: https://www.mmtimes.com/news/vice-president-sayscountry-needs-national-land-law.html.

Roy, P.S., Singh, I.J., Sarnam Singh, H.S.A., \& Sharma, C.M. (1993). Monitoring growth conditions of monospecies forest plantations using satellite remote sensing and geographic information system. Paper presented at the International Symposium on Operationalisation of Remote Sensing. ITC, Enschede, The Netherlands, April 19-23, 1993.

Scurrah, N., Hirsch, P., \& Woods, K. (2015). The political economy of land governance in Myanmar. Mekong Regional Land governance. Retrieved from: http://mrlg.org/wp-content/ uploads/2015/12/Political_Economy_of_Land_Governance_in_Myanmar_FA_2.pdf.

Trautwein, C. (2016, May 5). One-year logging ban proposed. Myanmar Times.

Turner, B.L. II, Clark, W.C., Kates, R.W., Richards, J.F., Mathews, J.T., \& Meyer, W.B. (Eds.). (1990). The earth as transformed by human action: Global and regional changes in the biosphere over the past 300 years. United Kingdom: Cambridge University Press.

Turner, B.L. II, Skole, D., Sanderson, S., Fischer, G., Fresco, L., \& Leemans, R. (1995). Land-use and land-cover change: Science/research plan. Report no. 35/7. Stockholm, Sweden: Royal Swedish Academy of Sciences.

Wilson, G., \& Bryant, R.L. (1997). Environmental management: New directions for the twenty-first century. Bristol, PA: UCL Press. 
Open Access This chapter is licensed under the terms of the Creative Commons Attribution 4.0 International License (http://creativecommons.org/licenses/by/4.0/), which permits use, sharing, adaptation, distribution and reproduction in any medium or format, as long as you give appropriate credit to the original author(s) and the source, provide a link to the Creative Commons license and indicate if changes were made.

The images or other third party material in this chapter are included in the chapter's Creative Commons license, unless indicated otherwise in a credit line to the material. If material is not included in the chapter's Creative Commons license and your intended use is not permitted by statutory regulation or exceeds the permitted use, you will need to obtain permission directly from the copyright holder.

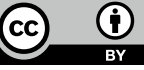

